\title{
Positive and negative aspects of forestry conflict: lessons from a decentralized forest management in Indonesia
}

\author{
Y. YASMI ${ }^{1}$, J. GUERNIER ${ }^{1}$, and C.J.P. COLFER ${ }^{2}$ \\ ${ }^{1}$ Regional Community Forestry Training Center for Asia and the Pacific (RECOFTC), P.O Box 1111 Kasetsart University, \\ Paholyothin Rd., Bangkok 10903, Thailand \\ ${ }^{2}$ Center for International Forestry Research (CIFOR), Jl. CIFOR, Situ Gede, Sindang Barang, 16680 Bogor, Indonesia
}

Emails: yurdi@recoftc.org, john@ recoftc.org, c.colfer@cgiar.org

\begin{abstract}
SUMMARY
Decentralization in natural resource management (NRM) is increasingly promoted as it is believed to offer better management. This study explores the positive and negative aspects of the forestry conflict that sometimes increases with decentralization. Drawing upon the results of a case study from Sumatra, this study examines how forestry conflict under decentralization processes was viewed by stakeholders. The conflict involved a logging company and a local community, and centered on a disputed forest boundary. The community accused the company of logging within the boundaries of its communal forest. In contrast, the company argued that it was logging within a state forest and was legally protected because it held a legitimate permit issued by the government. It is obvious that the conflict revolved around property rights claims. While forestry conflict is often viewed as a purely negative phenomenon this study shows that forestry conflict has both negative and positive sides. Stakeholders had both negative and positive perceptions of the issue. Conflict was seen to accelerate deforestation, sour relationships and generate high social risk. On the other hand, stakeholders suggested that conflict also created opportunities to participate in forest management, allow negotiation and stimulate learning. To address conflict under decentralization, property rights claims (de facto vs. de jure) need to be addressed and reconciled through negotiation processes so that positive aspects of conflict can be fostered and negative ones can be avoided. Additionally, decentralization needs to be prepared and implemented with care. Strong legal frameworks, clear implementation guidelines and capacity building for stakeholders are important elements that can contribute to the effectiveness of decentralization.
\end{abstract}

Keywords: Forest conflict, decentralization, stakeholder perception, Sumatra, property rights, negotiation, Indonesia, logging

Aspects positifs et négatifs des conflits forestiers: leçons d'une gestion décentralisée des forêts en Indonésie

\section{Y.YASMI, J. GUENIER et C.J.P. COLFER}

La décentralisation dans la gestion des ressources naturelles (NRM) est promue de façon croissante, étant perçue comme à même d'offrir une meilleure gestion. Cet étude explore les aspects positifs et négatifs du conflit forestier qui s'acroît parfois avec la décentralisation. En tirant des conclusions d'une étude cas en provenance de Sumatra, cette étude examine la manière dont le conflit forestier durant les processus de décentralisation a été perçu par les parties prenantes. Le conflit impliquait une compagnie de coupe de bois et une communauté locale, et se centrait sur une limite forestière disputée. La communauté accusait la compagnie d'exécuter des coupes à l'intérieur des limites de sa forêt communautaire. La compagnie, par contre, affirmait qu'elle travaillait dans une forêt d'état, et qu'elle était par conséquent protégée, car elle possédait un permis légitime délivré par le gouvernement. Il est clair que le conflit se centrait sur les droits à la propriété. Bien que les conflits forestiers soient souvent perçus comme un phénomène purement négatif, cet article démontre qu'ils ont également des aspects positifs. Les parties prenantes avaient des perceptions à la fois négatives et positives. Le conflit était perçu comme accélérant la déforestation, aigrissant les relations et créant un fort risque social. D'un autre côté, les parties prenantes suggéraient que le conflit créait également des opportunités de participer à la gestion forestière, de permettre la négotiation, de stimuler la connaissance. Pour faire face à ce conflit durant la décentralisation, les droits à la propriété ( de facto/ de jure) doivent être examinés et réconciliés au moyen de processus de négotiations, afin que les aspects positifs du conflit puissent être retenus, et les aspects négatifs évités. De plus, la décentralisation doit être préparée et mise en pratique avec soin. Des structures légales solides, un guide de mise en pratique clair et un agrandissement du pouvoir des parties prenantes sont des éléments importants pouvant contribuer à l'efficacité de la décentralisation.

\section{Aspectos positivos y negativos de conflictos forestales: experiencias de gestión forestal descentralizada en Indonesia}

\section{Y. YASMI, J. GUERNIER, y C.J.P. COLFER}

En cuanto al manejo de recursos naturales, se promueve cada vez más la descentralización, ya que se cree que fomenta una gestión más eficiente. Este estudio analiza los aspectos positivos y negativos del conflicto forestal que puede ser agravado por el proceso de 
descentralización. El estudio utiliza los resultados de una encuesta realizada en Sumatra para examinar como el conflicto forestal ocasionado por procesos de descentralización fue considerado por parte de los grupos interesados. El conflicto estalló entre una empresa maderera y una comunidad local, y se centró en una línea divisoria en litigio. La comunidad acusó a la empresa de talar árboles dentro de los límites de sus bosques comunales, y por otra parte la empresa expresó el punto de vista de que la tala se realizaba dentro de un bosque de propiedad estatal, y que gozaba de protección legal por disponer de un permiso legítimo emitido por el gobierno. Resulta evidente que el conflicto giraba en torno a derechos a la propiedad, y aunque se suele considerar el conflicto forestal como fenómeno exclusivamente negativo, este estudio demuestra que tiene aspectos positivos y negativos. Los grupos interesados expresaron puntos de vista negativos y positivos sobre el tema, y se comprobó que el conflicto acelera el proceso de deforestación, amarga las relaciones y genera altos riesgos de tipo social. Por otra parte, los grupos interesados sugirieron que el conflicto creaba también oportunidades para la participación en la gestión forestal, permitía las negociaciones y fomentaba el proceso de aprendizaje. Para resolver conflictos que suceden durante procesos de descentralización, hay que considerar y resolver las reivindicaciones de derechos a la propiedad (de facto vs. de jure) a través de procesos de negociación, para que se pueda fomentar los aspectos positivos del conflicto y evitar los aspectos negativos. Además, el proceso de descentralización debe ser preparado e implementado con mucho cuidado, ya que un marco legal sólido, pautas claras para la implementación y la creación de capacidad entre los grupos interesados son elementos importantes que pueden contribuir a la eficacia de la descentralización.

\section{INTRODUCTION}

The commercial exploitation of Indonesia's natural forests did not begin until the late 1960s when it became the means to boost economic development under the New Order regime, led by the former dictator Soeharto. Since then, the Government of Indonesia (GoI) has issued logging permits to more than 500 logging concessions some of which were given to close relatives and cronies of Soeharto. The forestry sector expanded rapidly and by the 1990s Indonesia was among the largest producers of tropical wood (MoF 2004). During the second half of the 1990s, environmentalists and the international community increased pressure on the GoI because natural forests were being rapidly exploited and the rights of local people to manage and access forest resources were violated by many concession holders (WenbanSmith 2001, Yasmi, 2003). Local people were frequently intimidated and if they opposed logging operations they were threatened militarily (Yasmi 2003; McCharty, 2004; Wulan et al, 2004). The international community increasingly recognized that such a system was unacceptable. Moreover it became obvious that the GoI was unable to address resource management issues such as deforestation, injustice, human rights violations and poverty. The end of the 1990s was also marked by political instability and nationwide protests demanding an end to Soeharto's authoritarian regime. With the political situation becoming chaotic, Soeharto was forced to step down in 1998; this marked a new phase in Indonesian political history, a phase in which major changes took place, including within the forestry sector. Since then, Indonesia has been struggling to implement decentralization in various sectors, including natural resource management. The main shift in the forestry sector was characterized by local governments (i.e. district governments, kabupaten) being given an opportunity to participate and take control of forest management. For the first time in Indonesian history, district governments were given new authority to issue small logging concessions and collect forest taxes. In response, local governments throughout Indonesia started to grant two types of small logging permits, namely the Timber Product Utilization Permit (known as IUPHHK) ${ }^{1}$ and the Forest Product Harvesting Permit (HPHH) ${ }^{2}$. The IUPHHK could be granted to cooperatives, small- to medium-scale businesses and state-owned or privately owned enterprises, with a maximum size of 50000 hectares per permit. The HPHH, on the other hand, could be issued to individuals, farmers' groups and cooperatives, with a maximum area of 100 hectares per permit. These permits were the most popular, and were often called "100-ha concessions" owing to their size. This paper focuses on the HPHH.

Earlier studies demonstrated that HPHH implementation was marred by uncertainties about legal frameworks, high expectations for change and the struggle over property rights (Colfer and Resosudarmo 2002, McCarthy 2004, Barr et al. 2006, Engel and Palmer 2006, Komarudin et al. 2007, Palmer and Engel, 2008). It was therefore no surprise that its implementation generated various conflicts. Most of these conflicts have been rather destructive in nature, for example, logging companies had various disagreements with local communities, with some intensifying into violence (Schroeder-Wildberg and Carius 2003, Wulan et al. 2004; Yasmi 2008). The Indonesian experience seems to be similar to other forest conflicts elsewhere. As shown in a number of studies, forest-related conflict often results in hostility, distrust and even violence (Hotte 2001, de Jong et al. 2006, Ho 2006).

Whilst many forestry conflicts yield destructive outcomes, conflict scholars have long argued that social conflict has the potential to produce positive changes too, such as promoting improvement in resource governance, a clearer division of roles and responsibilities and new grounds for collaboration (Coser 1956, Deutsch 1973, Kriesberg 1998, Buckles 1999, FAO 2000, Castro and Nielson 2001, Bartos and Wehr 2002). However, in the forestry sector, particularly in the

\footnotetext{
IUPHHK stands for Ijin Usaha Pemanfaatan Hasil Hutan Kayu or Timber Product Utilization Permit.

${ }^{2}$ HPHH stands for Hak Pemungutan Hasil Hutan or Forest Product Harvesting Permit. In some regions in Indonesia, such as East Kalimantan this type of permit is also called IPPK (Ijin Pemungutan dan Pemanfaatan Kayu) or timber harvesting permit. In essence both terms refer to the same scheme.
} 
context of decentralization, there has been little attention to how stakeholders look at local level experience and perceive conflict. To what extent they perceive both negative and positive aspects of conflict remains unclear and thus needs further exploration. An understanding of their perceptions can provide a strong ground for devising efforts to address conflict appropriately and also to improve decentralization policies. This particular study examines a conflict between a small logging company and a local community in Sumatra in the context of the new logging regime, i.e. HPHH. The study analyzes how the disputants interacted during one particular conflict process and explores local perceptions about it (i.e. the degree to which they considered conflict to be a negative or positive phenomenon). The analysis strives to understand stakeholders' arguments based on their actual experience of forestry conflict.

\section{THEORETICAL REVIEW}

\section{A new mode of forest governance and conflict}

During the past two decades, the decentralization of NRM has received considerable attention in the literature. The worldwide movement towards NRM decentralization is viewed as an important instrument of environmental and development policy (Agrawal and Gupta 2005). Generally speaking, decentralization embodies the transfer of rights and authority from central to local governments (Larson 2002, Pacheco 2004, Nygren 2005, Ribot et al. 2006). In an "ideal" decentralization scheme, roles and responsibilities related to resource management between central and local governments are clearly defined and, at the same time, the role of civil society - such as through the empowerment of local people - is promoted. Decentralization is expected to bring wider participation of stakeholders such as ethnic minorities, women and migrants so that they can benefit from decentralization (Colfer and Capistrano 2005, Yuliani et al. 2007, Colfer et al. 2008).

Proponents of decentralization have put forward various arguments in support of resource decentralization. The failure of centralistic government regimes in managing natural resources sustainably is perhaps one of the primary reasons for decentralization. Additionally, decentralization is also argued to reduce government bureaucracy, to improve the efficiency of public service delivery and to provide more opportunities for participating in NRM, accountability and equity (Enters et al. 2000, Pacheco 2004, Resosudarmo 2004). Recent scholarly works also indicate that decentralization provides platforms that enable stakeholders to accelerate poverty reduction and at the same time conserve the remaining natural forests (Kaimowitz et al. 2000, Sikor 2001, Ribot and Larson 2005, Sunderlin 2006). In this context, donor agencies, major bilateral and multilateral programmes and development organizations have been promoting decentralization initiatives as part of their commitments to achieving democratic resource management and good governance in developing countries
(Ribot et al. 2006, World Bank 2007).

As decentralization increasingly receives political support, programmes and projects related to decentralization continue to be promoted by donor agencies (Enters et al. 2000; Ribot et al. 2006; World Bank 2007). However, real impacts on the ground in terms of equity, democracy, poverty reduction and resource conservation have been questioned recently by Tacconi et al. (2006). In some cases, real progress has been made and local actors, including local communities, can participate and benefit from decentralized forest management. In Indonesia, for example, Wollenberg et al. (2006) and Yasmi et al. (2006) describe how local communities did benefit from forest decentralization through income generation from community logging. However, in other circumstances, local governments are also frequently subject to bribery and political pressure from local resource users; "elite capture" is widespread, resulting in forest decentralization benefits being enjoyed by only a small number of elite groups (Kaimowitz et al. 1998, Barr et al. 2006, Komarudin et al. 2007). In addition, decentralization processes are often based on ambiguous legal frameworks and consequently their implementation can create uncertainties; for example, who has the rights to define forest boundaries and how equitable benefit-sharing schemes can be developed (Yasmi et al. 2006). Due to the plethora of ambiguities, the implementation of forest decentralization has sometimes been described as "chaotic" (Larson 2002, Wollenberg et al. 2007).

Another common problem associated with decentralization is the emergence of conflicts and power struggles at the local level. Stakeholders have disputes over benefit sharing, access to resources and property rights. Similar types of conflict have been observed in various locations in Asia, Africa and Latin America (Kaimowitz et al, 2000, Sikor, 2001, Colfer and Capistrano 2005, Ngakan et al. 2005, Ribot and Larson 2005, Ngakan et al. 2005, Yasmi et al. 2005). Those conflicts - as in any other NRM conflict - can be expected and may be unavoidable because stakeholders have differing and competing interests, perceptions and ideas about how NRM should be carried out (Buckles 1999, Castro and Nielson 2003). While there is a large body of literature that addresses NRM conflicts under the status quo (see Mardiros 1997, Bavinck 1998, Jentoft 2000, FAO 2000, Valladares-Padua et al. 2002, Wulan et al. 2004), more research is still needed on conflict under decentralization, particularly conflict that occurs during transitional phases such as in Indonesia.

\section{Positive and negative perceptions of forestry conflict}

Resource conflict is more prevalent nowadays and that this is not merely an illusion generated by more research (Blench 1996). There are more people competing for fewer resources and there are more perceived resource arenas (Kaplan 1994; Homer-Dixon 1999). Moreover, rapid socio-political changes such as globalization and decentralization have also brought with them enormous conflicting issues for resource management (Schäfer, 2001). According to FAO (2000), 
conflicts occur if there are contradictions between local and introduced management systems, misunderstanding and lack of information about policy and programme objectives, contradictions or lack of clarity in laws and policies, inequity in resource distribution, or poor policy and programme implementation. Historical relationships and power differences among actors are also sources of conflicts. Depending on the underlying issues and the ways they are being addressed, NRM conflicts can yield various impacts and consequences.

Although NRM conflict is usually viewed as a negative phenomenon there are two schools of thought in the interpretation of the role of social conflict, including issues related to NRM. The first belongs to the so-called "functionalists" - employing the "harmonic" idea — that perceives conflict to be a hindrance, messy and dysfunctional (Bailey 1997). This school associates conflict with a threat to the status quo in the sense of disruption of reliable and stable conditions (Kriesberg 1998). Conflict is also considered to generate hostility, distrust and hatred and thus is to be avoided at any cost. The second school argues that conflict may result in dysfunctional situations but also may offer constructive outcomes (Castro and Nielson 2001). This belief is inspired by interpretations of social conflicts as valuable ties that hold modern democratic society together and provide it with the cohesion that it needs (Hirschman 1994). In the same vein, Mack and Snyder (1957) argue that conflict could encourage collaboration, improvements on outdated patterns and a more efficient division of labour. Today researchers have moved beyond dichotomizing conflict as being either positive or negative (Bailey 1997, Walker and Daniels 1997, Kriesberg 1998,Glasl 1999). If managed adequately, positive outcomes of NRM conflict routinely emerge. These can include reaching agreements and improved resource management (e.g. via better collaboration). On the other hand, if addressed badly, it may carry negative overtones, e.g. bad relationships, destruction of resources and violence.

The emphasis on local views requires recognition that culture has a significant influence on such perceptions. In a study involving 30 sites in 11 countries, the level of conflict at each site was evaluated (Colfer 2005). But this externally determined level proved different from people's attitudes toward conflict. Colfer found dramatic differences in local people's views on the social acceptability of conflict. Within this data set, Indonesia was the country in which conflict was generally considered to be the most undesirable. In many parts of Indonesia, including the location for this case study, daily life is marked by smooth social relations. People make determined efforts to maintain good relations, kindness is highly valued and empathy is common. When serious conflicts do surface, social ruptures can be very severe (from permanently broken friendships to violent confrontations). Contrariwise, in many areas in Brazil or Cameroon, for instance, conflict is a routine part of daily life and regarded as an acceptable phenomenon. One regularly hears people arguing on the street and in stores. People become angry and then conciliate, as a normal part of life. This kind of qualitative difference has implications for the applicability of our results to other contexts.

\section{METHODS}

The selection of Sumatra as a case study area was based on a number of criteria. Firstly, as mentioned earlier, considerable forestry conflict has emerged in Sumatra since the implementation of decentralization policies and formal study of forestry conflicts in Sumatra had been relatively limited. Secondly, Sumatra is relatively accessible compared to other places in Indonesia such as Kalimantan or Papua; this facilitated fieldwork within the limited timeframe available (August to November 2004) ${ }^{3}$. Although the fieldwork was carried out in late 2004, the authors' engagement in the area continues to date. We regularly monitor activities related to forest decentralization in Sumatra, via learning events, workshops, regular exchanges with onsite researchers and field visits. Thirdly, the Center for International Forestry Research (CIFOR) has carried out interdisciplinary research in the area, which has benefited this study, particularly in terms of obtaining secondary data (Kusumanto et al. 2005, Adnan et al. 2008). Finally, Bape ${ }^{4}$ village where this study was carried out has been exposed to conflict with various logging companies since the mid 1970s (Colfer 2005). Although the community had long experience of conflict with local companies, there has been no systematic research to investigate how these conflicts occurred, developed and how stakeholders perceived them.

In order to understand how stakeholders engage in conflict and how they perceive it, various data acquisition methods were used, namely: semi-structured interviews, focus group discussions (FGD) and expert consultation. Twentyeight semi-structured interviews were conducted with key respondents; each lasted between 45 minutes and two hours. These respondents were divided into three groups: community members, the logging company and outsiders (Table 1). The first two groups are the conflicting parties. The outsiders are those who are not directly involved but are stakeholders in the area, i.e. the District Forest Service (DFS), researchers and local non-governmental organizations (NGOs). The number of respondents represents the data saturation point; the point at which further interviewing of more respondents ceased providing additional substantive information (Guest et al., 2006). Given the cultural context and socio-political structure of the community in the study area, it proved difficult to interview female informants. ${ }^{5}$ Hence, gender-related concerns are inadequately captured in this study.

\footnotetext{
3 The first author was also born and raised in the adjacent province, so understood most of the local language, which also facilitated the research.

${ }^{4}$ This name is fictional.

${ }^{5}$ Most of the interviews were conducted by Y. Yasmi, who is male.
} 
During the interviews, respondents' knowledge and perceptions of the conflict were explored. The approach taken was as follows:

- To investigate how the logging company and local community engaged in the conflict, respondents were asked to describe the underlying issues involved, the development of the conflict and what strategies the company and local community used in coping with it.

- To explore respondents' perceptions, they were asked whether they viewed the conflict as a positive or negative phenomenon; they were further asked to explain their perceptions.

Besides interviews, two FGDs with members of the local community were performed. Findings were cross-checked with experts who had been working in the area for a long time. Finally, we analyzed our data primarily through

TABLE 1 Characteristics of respondents

\begin{tabular}{rlc}
\hline \multicolumn{2}{l}{ Respondents' characteristics } & Number $(\mathbf{n})$ \\
\hline 1. Origin & \\
\hline$\bullet$ & Local community & 18 \\
\hline$\bullet$ & Logging company & 3 \\
\hline$\bullet$ & Outsiders & 7 \\
\hline Total & & $\mathbf{2 8}$ \\
\hline
\end{tabular}

\begin{tabular}{rlc}
\hline \multicolumn{2}{l}{ 2. Gender } & \\
\hline$\bullet$ & Male & 24 \\
\hline$\bullet$ & Female & 2 \\
\hline Total & $\mathbf{2 8}$ \\
\hline
\end{tabular}

qualitative content analysis of the interview texts following iterative steps (e.g. data reduction, categorization, adjustment of categories) described by Mayring (2000); this enabled us to recognize general patterns in our data. In presenting the results, we provide simple statistics (i.e. charts, tables) and also quote the respondents directly to illustrate how they perceived the conflict.

\section{STUDY LOCATION AND STAKEHOLDERS}

This study was carried out in Bape village, which is part of Bungo district in Jambi, Central Sumatra (Figure 1). In this area, like in most parts of Indonesia, forests have been under significant pressure from logging operations since the early to mid-1970s (Kusumanto et al. 2005, Adnan et al. 2008). The interaction of local people with the logging companies in the past were also marred by various conflicts. However, at that time they could not actively oppose loggers as concession holders were guarded by the military. Ekadinata and Vincent (2008) provided remote sensing data that showed substantial forest cover loss between 1970 and 2002. Since then, at least four large logging concessions (totaling an area of more than 250000 hectares per concession) have operated in the vicinity of the village and have transformed the landscape from dense primary to secondary forests (Indriatmoko 2002). These concession-holders terminated their operations in early 2000 due to the decreasing number of accessible trees

FIGURE 1 Jambi province where Bape village and Bungo district are situated

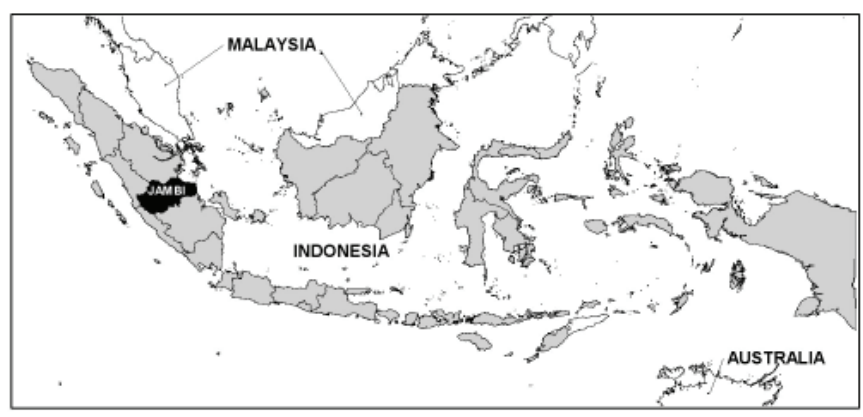

and the expiration of their permits. Today, the remaining "virgin" forests are almost entirely limited to locations either inaccessible via road or situated within national parks. After decentralization policies took effect in 2001, HPHH permits were issued by various district heads to local logging companies, cooperatives and community groups in all districts in Central Sumatra. The issuance of these permits was made possible under the new decentralization policies.

Within Bungo district dozens of small logging concessions received HPHH permits from the district head. Nevertheless, the district office was unwilling to release details of the locations and extent of the areas in which these concessions were operating. In the vicinity of Bape village, one small logging concession was operating. After receiving the permit from the head of Bungo district in early 2004, the concession established a logging camp in the forest and employed around 50 loggers who came from other part of the island or from Java. Since its inception, there has been dissension between this concession and the community of Bape over the delineation of the forest boundary. The people of Bape perceived the concession area to overlap with their traditional forest.

The local community of Bape comprises 226 households with a total population of 624 based on a census taken in 2004 (Sari 2008, Yasmi 2008). Most of the community members are poor (e.g. low incomes, poor infrastructure and limited access to health and education services). The village was one of the least developed villages in Central Sumatra when CIFOR began working there in 2000 (Kusumanto et al. 2002). In 2004, less than 5 percent of the village population had completed high school. Due to its remote location, there is limited opportunity for economic activities in the village. Until mid- 2008, the community had primarily practiced swidden agriculture with rice as their main crop supplemented by rubber, though recent high oil palm and rubber prices have encouraged a significant shift. To obtain cash income, community members establish rubber plantations and sell forest products on an occasional basis. 
The village head in Bape observed that most of the men in his village cut logs from the forest, particularly if they need cash income. The community cuts trees in the forest around the village on a selective basis to ensure the survival of their communal forest. For example, if people need money, they enter the forest for two or three days in groups of three to six and fell a limited number of large trees. They sell the timber to local sawmills operating in the $\operatorname{district}^{6}$ (Colfer et al. 2005: p268). The presence of small logging concessions in their village area was considered to be a threat to community incomes and the survival of their communal forest. The next section discusses the way in which the local community and the logging company locked horns.

\section{RESULTS}

\section{The underlying issues in the Sumatran conflict}

The district office in Bungo confirmed to us that they only issued logging permits within the state forest area. In reality in many parts of Indonesia including Sumatra state forest areas often overlap with community forests. This situation was mainly due to the fact that the state forest areas were delineated on the map only by the Ministry of Forestry in Jakarta and with no ground truthing. During the Soeharto's regime era contestation of state forest land was seen as a subversive act and subject to military oppression. Therefore, local communities were afraid to claim communal forests and, in accepting that all forests were state forests, were inevitably marginalized from forest management activities. When the HPHH scheme emerged after the demise of Soeharto's regime, communities started to re-claim their forests - thus struggle over access to forest and property rights is at the core of the conflict. The main issue fuelling the conflict in the study area was a dispute over the official forest boundary. The Bape community claimed that the logging company operated in the communal forest; this was deemed unacceptable and considered as a denial of the community's rights over forests. In addition, the local community perceived logging as a threat to its income as the company exploited the forest used by the community for specific cash needs. The local community argued that the company ignored their rights to the forest, as described by a respondent:

The logging company operates in our communal forest. It did not ask permission from us before entering our forest. It logs all trees including small ones too. We are worried that our forest will be destroyed entirely. Its operation must be stopped immediately!

The local community demanded that logging operations should cease and, at the same time, asked for compensation such as village hall renovation and fees for all trees felled in its communal forest. During one of the FGD sessions, a traditional leader said that the operation of the company was highly detrimental. He indicated that every day many logs were removed from the forest. He stressed the importance of stopping the company's operations in order to save the communal forest on which the local community was highly dependent. His opinion was shared by most community members who also considered that taking immediate action to prevent the company from continuing its logging operations was imperative. According to the local community, the unclear boundary between state and communal forest as well as the economic interests involved induced the company to operate in their area.

In stark contrast, the company held a completely different opinion of the conflict, arguing that it logged within state forest land. According to the company, it received a logging permit from the head of the district and therefore its operation was legal and in accordance with the new decentralization policies. It showed us the map of its concession area delineated within the state forest area and approved by the DFS. When asked for a copy of the map, the company refused. ${ }^{7}$ In addition, the company considered the opposition from the local community to be illogical and "economically" driven. Its personnel accused the community of having an economic interest by asking for compensation and fees. A company staff member lamented:

We are not operating in the communal forest.
You know, we received a legitimate permit from
the district head and our concession area falls
within the state forest. See this map (he showed
us the map of the concession area). You have to
understand the claim of the local community is
economically motivated. They want money from
us, they ask us to pay fees for the trees that we
cut down. This is unacceptable. Well, if they
claim the area as their communal forest, please
show me the map of that communal forest. They
don't have any map, so how can they claim the
area as theirs and why do they keep asking for
money from us?

\footnotetext{
${ }^{6}$ Women had limited opportunities for accessing cash income as they were heavily involved in cultivating rice. Nevertheless, some women started to make handicrafts, like tissue cases or bags, out of non-timber forest products such as bamboo. This new initiative is part of the participatory action research that was facilitated by CIFOR and local NGO partners (Sari 2007).

7 In Indonesia, researchers often have difficulty obtaining maps of concession areas. A concession map is considered private, not public property as in the case of many developed countries. Our problem was not an isolated case but an endemic problem in Indonesia.

8 We understood from the company that they did not want to pay anything to the community because they perceived the community's demands to be largely economically-driven. The company also mentioned that the district office had assured it that the area where it operated was state forest. They believed that what the community wanted was only "money" and that if they ever gave the community money, such requests would continue in perpetuity.
} 
One clear element of this conflict is the ambiguity over the forest boundary and the ensuing struggle over property rights (de jure vs de facto), which can also be linked to the past history of forest management in Indonesia. For example, a respondent from the DFS explained that in the past during the Soeharto era all forest areas were classified as state forest. Communal forests were rarely acknowledged. The traditional rights of a local community to its forest were ignored. As decentralization of forest management was promoted after Soeharto, many traditional communities struggled to get their communal forests recognized. In fact, Bape was one of the traditional communities that has strived to obtain legitimate recognition of its communal forest, with help from NGOs and CIFOR. Therefore, when a logging company operated in the communal forest, opposition from the community members was not unexpected. When asked why the district government issued the concession to an area that overlapped with the communal forest, a staff member of the DFS said that the district government - particularly the DFS - did not have sufficient human and financial resources to map all the communal forests. He honestly and openly stated that the concession area was drawn on paper in the district capital without a ground check. It appeared that the main objective of the district government was to generate district income from this concession and it did not have good, reliable baseline maps.

\section{The interaction of stakeholders in the conflict and their strategies}

Table 2 shows the chronological development of the conflict, indicators for each stage of conflict development and the approximate time when each stage occurred. The anxiety stage reflects the anxiety felt by local community members due to the logging activities in their communal forest. This stage was experienced by the community between March and May 2004. During this period, the community became very irritated with the logging company's operations. These sentiments were exacerbated as the company did not request permission prior to commencing logging. Thus many community members were very upset. Rumors of the logging activity quickly spread throughout the village. Village leaders and members began to discuss how to handle the situation and met several times to find strategies to deal with the company.

After several meetings were held, the local community decided to enter into the so-called debate stage (i.e., stage 2) with the logging company for two main reasons. Firstly, they increasingly saw logging as a denial of the community's rights to the forest. Secondly, there was also a fear among community members that, if they did not put a stop to the logging, they could lose their communal forest forever. The debate stage between the company and local community lasted from June to August. During this period, the local community argued with timber operators that the forest where logging activities were taking place was communal forest. Representatives from the local community also visited the logging company office and tried to explain to
TABLE 2 The chronological development of the conflict

\begin{tabular}{|c|c|c|}
\hline Conflict stage & Observed indicators & Period \\
\hline 1. Anxiety & $\begin{array}{l}\text { Villagers' feeling of worry } \\
\text { about the loss of forest; } \\
\text { villagers anger with logging } \\
\text { company; complaints about } \\
\text { the logging operation; } \\
\text { disappointment among } \\
\text { villagers }\end{array}$ & $\begin{array}{l}\text { May to } \\
\text { March }\end{array}$ \\
\hline 2. Debate & $\begin{array}{l}\text { Arguments with the } \\
\text { concession operator; debate } \\
\text { at the company's office; } \\
\text { verbal clash in the forest }\end{array}$ & $\begin{array}{l}\text { June to } \\
\text { August }\end{array}$ \\
\hline 3. Lobby & $\begin{array}{l}\text { Lobbying for compensation; } \\
\text { negotiating the sum by } \\
\text { lowering the fees requested } \\
\text { from the company }\end{array}$ & September \\
\hline 4. Protest & Protest at the logging site & November \\
\hline 5. Intimidation & $\begin{array}{l}\text { Threats to burn down the } \\
\text { camp; threats to confiscate } \\
\text { logging equipment; threat to } \\
\text { kill logging operators }\end{array}$ & November \\
\hline
\end{tabular}

the company manager that their communal forest was being destroyed by the logging operation. During the debate stage, quarrelling was continuous. As part of the strategy, the local community persisted in demanding that logging be stopped and that the company must pay a certain fee for all the trees that were cut from the communal forest. In addition, the local community also asked the company to help improve village infrastructure such as the village hall and mosque.

Despite all these demands, the company continued to maintain its position arguing that its operation was legitimate and within the state forest boundary. It refused all the community's demands. As a result, the local community became very frustrated. Through their representatives, the local community continued to lobby the company for about a month in September 2004 (i.e. stage 3). Representatives visited the company office again and discussed the possible forms of compensation, even lowering the fees they initially requested the company to pay. Nevertheless, from the community's perspective, this effort also ended unsatisfactorily, as the company remained unwilling to respond positively. At this point, the local community lost all patience and chose to conduct a protest against the company (i.e., stage 4). Ten people, mainly local leaders, travelled to the logging site and made harsh demands for a halt to all current logging activities. During this protest, community members carried machetes to demonstrate their serious intent.

Subsequently, logging activities ceased entirely for a few days. However, soon after, local community members returned to the site and again demanded compensation after receiving news that logging had resumed. However, the staff at the site replied that they did not possess the authority to make decisions related to compensation and suggested that the local community discuss the issue with the board of 
management in the capital city. At this point, local community members were no longer able to accept the fact that their demands were still not being heard. They subsequently launched intimidation tactics (i.e. stage 5) against locally based workers by threatening to burn down the logging camp and all logging equipment if the company did not offer acceptable compensation. They also threatened to murder logging workers if the company did not immediately cease logging activities. As a result, logging activities were again closed down. This intimidation stage was the culmination of the conflict. All logging activities were stopped immediately due to the gravity of the situation; it appeared that there was no solution.

It is important to mention here that the local community informed the district government and DFS about their conflict. However, neither institution was willing to intervene for various reasons. DFS claimed that it had no staff capable to handle the situation and it was under-staffed. It mentioned that it was the responsibility of both parties to resolve the conflict. Similar explanations also were provided by the district government.

\section{Stakeholders' perceptions on the conflict in Sumatra}

Overall, respondents perceived negative and positive aspects of the conflict at the same time. The negative dimensions were elaborated by respondents, as illustrated in Figure 2. From the figure we can see that slightly more than onethird of the respondents ( 36 percent) perceived the conflict to have had a negative impact on the forest, referring to "destruction of the forest". This view was shared by the local community who accused the company of destroying its communal forest through logging. During one of the FGD sessions with local community members, it was mentioned that the local community often associated conflict with the loss of community control over forest. It appeared that the local community considered the conflict to be quite negative because it could not prevent logging in its communal forest. One of the respondents explained that the conflict even triggered an intensification of logging company activities:

\section{.... because we confront their operation in our communal forest, they (i.e. the logging company) will continue to increase timber felling. I can tell you this because they are afraid of the community's demand to stop their activities. So, they will cut all the trees very quickly now because they may not be able to do so any more in the near future, because they know that we will force them to leave our territory.}

Another negative dimension was the high social risk as argued by 32 percent of the respondents. The social risks were mainly linked to high intensity activities such as protest and intimidation. Respondents argued that such high intensity conflict could be difficult to control and might turn violent. One of the respondents from the DFS explained that the social risks were already evident. The conflict triggered anger and destructive behavior such as the threat to confiscate logging equipment and kill logging operators. From the perspective of the logging company, conflict was damaging to operations as logging activities ceased several times and, in the end, stopped entirely. This caused serious financial loss to the company. Moreover, its logging operators were traumatized by the intimidation. Similarly, respondents from the local community also maintained that the social risks could be intolerable. For example, if the conflict had continued, physical engagement might have been inevitable.

Furthermore, 14 percent of the respondents considered the issue to be costly. To engage in conflict was timeconsuming, for example, as community members were forced to lobby and negotiate with the company. According to the village head of Bape, conflict required much energy and thinking. Moreover conflict was also perceived to result in bad relationships (11 percent) with hard feelings between the disputants. Finally, some respondents from the logging

\section{FIGURE 2 Negative dimensions of the conflict}

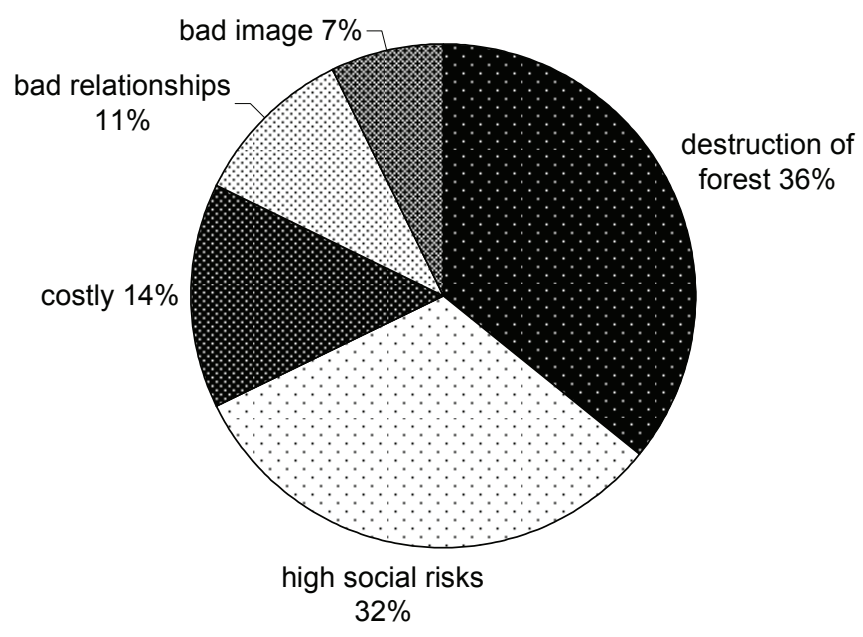

company (7 percent) suggested that conflict created a bad company image. They realized this as soon as the conflict became known by the wider public in the district particularly after the various debate and protest stages. Inability to deal effectively with the local community was deemed a failure by the company to address social issues. For a commercial company this inability would be translated as bad corporate social responsibility. This negative image would tarnish the company's reputation and future business in the region.

Despite the many negative aspects, a number of positive elements were also noted by the respondents (Figure 3). Onequarter of the respondents indicated that the conflict provided an opportunity for the local community to participate or "have a say" in forest management, for example by resisting detrimental logging activities. An NGO facilitator believed this to be a positive development compared to the situation during Soeharto's centralistic era. During that time, local communities were unable to have any influence on forest management as opposition to logging was controlled militarily. Under decentralized forest management, to some 
extent the local community in Bape was considered to be able to exercise its power too. One respondent said that opposition by the local community sent a clear message that the logging company could no longer operate in isolation and that the local community's interests and aspirations must be taken into account seriously. Some respondents (14 percent) also argued that conflict allowed communication and negotiation to take place. In this case, conflict stimulated disputants to engage in a series of negotiation processes. To be able to spontaneously engage in negotiation was considered an

\section{FIGURE 3 Positive dimensions of the conflict}

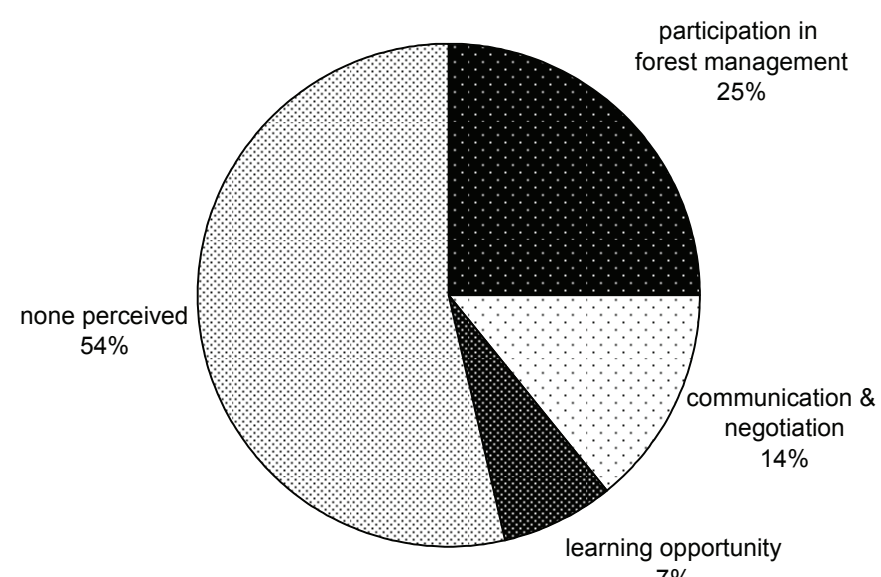

$7 \%$

important first step in conflict resolution. Some 7 percent of the respondents suggested that the conflict provided disputants with a learning opportunity, i.e., triggering reflection on what should be improved in terms of forest management given the current decentralization initiatives. Finally, 54 percent did not mention any positive elements; they had no concept of how the conflict could be regarded as a positive phenomenon.

A further detailed analysis of the perceptions of each stakeholder group revealed interesting results (Table 3). Stakeholder opinions about the conflict seem to be in stark contrast with each other. For example, the local community considered the destruction of the forest as the most negative dimension (i.e. 10 out of 18 respondents). This is understandable as the company increased logging intensity after they engaged in conflict with the community. On the other hand, the logging company had a very different perception. It considered the conflict to be negative primarily in terms of the impact on its reputation as it had developed a negative image (two out of three respondents). The company felt this very strongly after various protests from the community were publicized to the wider public in the district. Meanwhile, outsiders (i.e. the DFS, researchers and local NGOs) seemed to consider the high social risks as the worst impact, e.g. intimidations, physical threats. Those kinds of phenomena could lead to serious problems, such as open fight and killing..

Different perceptions were also quite apparent with regard to the positive dimensions. Four respondents from the local community said that the conflict allowed them to influence forest management and two respondents suggested that conflict triggered their efforts to communicate and negotiate with the company. However, the majority of the respondents

TABLE 3 Negative and positive dimensions of the conflict

\begin{tabular}{|c|c|c|c|}
\hline Perceptions of conflict & $\begin{array}{l}\text { Local } \\
\text { comm. } \\
(n=18)\end{array}$ & $\begin{array}{c}\text { Logging } \\
\text { company } \\
(n=3)\end{array}$ & $\begin{array}{l}\text { Outsiders } \\
\quad(n=7)\end{array}$ \\
\hline \multicolumn{4}{|l|}{ Negative dimensions } \\
\hline $\begin{array}{ll}\text { - } & \begin{array}{l}\text { Destruction of } \\
\text { forest }\end{array}\end{array}$ & 10 & 0 & 0 \\
\hline - $\quad$ High social risks & 5 & 1 & 3 \\
\hline - $\quad$ Costly & 2 & 0 & 2 \\
\hline - $\quad$ Bad relationships & 1 & 0 & 2 \\
\hline - $\quad$ Negative image & 0 & 2 & 0 \\
\hline \multicolumn{4}{|l|}{ Positive dimensions } \\
\hline $\begin{array}{ll}\text { - } & \text { Participation in } \\
& \text { forest management }\end{array}$ & 4 & 0 & 3 \\
\hline $\begin{array}{ll}\text { - } & \text { Communication \& } \\
\text { negotiation }\end{array}$ & 2 & 0 & 2 \\
\hline $\begin{array}{ll}\text { Learning } \\
\text { opportunity }\end{array}$ & 0 & 0 & 2 \\
\hline - $\quad$ Not described & 12 & 3 & 0 \\
\hline
\end{tabular}

did not perceive any positive aspect (see Table 3 ). From the company's perspective, there was no positive aspect at all. The conflict was considered to "kill and ruin" its business; it was entirely destructive. Finally, all seven respondents from the outsiders' group argued that the conflict provided at least three positive aspects: enabling the local community to participate in forest management, allowing negotiation and creating a learning opportunity for disputants.

\section{DISCUSSION AND CONCLUSIONS}

Throughout this study we have described how the new logging regime (HPHH) under the decentralization system in Sumatra was implemented. It is obvious that the implementation of such logging schemes resulted in serious conflict between the logging company and the local community. In line with previous studies (Colfer and Resosudarmo 2002, McCarthy 2004, Barr et al. 2006), our study strengthens the argument that this conflict was mainly caused by unclear boundaries between state and communal forests. The conflict was about struggle over access and control of forest resources due mainly to weak property rights arrangements (see Engel and Palmer 2006, Palmer and Engel, 2008). The difference between de jure and de facto claims over forest resources were the main issue in the conflict. On the one hand, the logging company considered the forest as the property of the state which it has received legal permission to log. On the other hand, the community perceived the area as their own forest, which they had managed and used for a long time, 
e.g. they have long practiced swidden agriculture and cut trees from the forest to generate cash income. They thus saw external logging activity as a violation of their rights to their forest. This study also confirms the findings of other studies that demonstrate acute conflict under the new decentralized governance structure (e.g. Kaimowitz et al, 2000, Sikor, 2001, Colfer and Capistrano 2005, Ribot and Larson 2005).

Furthermore, while forestry conflict is often seen as a negative phenomenon, particularly in Indonesia, this study demonstrates that stakeholders perceive forestry conflict as having both negative and positive elements (see Table 3, Figure 2 and Figure 3). Our findings thus demonstrate that dichotomizing conflict as either clearly positive or clearly negative is not appropriate in the forestry context. The same argument for social conflict in general was echoed earlier by Bailey (1997), Walker and Daniels (1997), Kriesberg (1998) and Glasl (1999). Despite the existence of both positive and negative aspects of conflict, one observation from this study is that the negative aspects are still considered dominant over the positive ones. This is indicated by the ability of all respondents to elaborate the negative aspects, though with differing emphases, while positive aspects were only seen by half of them (54\%) - see Figure 3. The logging company did not consider anything positive from the conflict (see Table 3). Perhaps, this phenomenon can be explained by the fact that the conflict was not addressed in a timely or appropriate manner as it intensified over time and even developed into the protest and intimidation stages. Such high intensity conflict is usually difficult to regulate as actors start to lose control over their actions. Additionally, high intensity conflict can be regarded as a situation that has gone "too far", sometimes evolving into a situation of "no return". An important lesson that we can learn is that forestry conflict - or any conflict should be addressed in as timely a manner as possible before it intensifies. Once it intensifies it will be more difficult to resolve as it will require more resources. The dominance of negative perceptions may also be linked to earlier arguments put forward by Colfer et al. (2005) where they argue that Indonesian society in general is not used to overt conflict. In general, Indonesians value highly harmonious relations, with conflict seen as something to be avoided. This study suggests that Indonesian society is changing and that conflict may be an unavoidable part of forestry. The repressive approach taken by Soeharto's regime was not helpful. Our study (and others) suggests that conflict is almost inevitable in forest management contexts. Greater acceptance of this fact can increase the likelihood that groups can manage that conflict in a benign way, including developing more effective coping mechanisms.

The most difficult challenge that remains is how we can define the constructive limits of NRM conflict and how we can ensure that conflict is regulated within these limits. While Glasl (1999) suggests that constructive conflict is defined specifically by the ability to reach an agreement and avoid destructive escalation levels, in NRM the limits to constructive conflict remain unknown. We propose, in NRM contexts, using positive consequences as possible indicators of constructive conflict. Put differently, it is perhaps logical to assume that when conflict leads to a better relationship among actors in conflict, improved trust and a better and/or more equitable resource management, such conflict can be considered constructive. Furthermore, the constructive limits can also be linked to escalation levels. Our empirical research in Sumatra suggests that the delineation of constructive limits requires attention to multiple perspectives. The different framing and experience of conflict by different actors is shown in Table 3 . What is considered destructive by one group may not necessarily be so considered by others. For example, the intimidation phase was considered harmful and destructive by the logging company but the local community felt the necessity to do so in order to prevent logging in the communal forest.

Our study, under conditions of forest decentralization, raise important questions about the extent to which decentralization goals such as equity, democratization and resource conservation can be effectively achieved. A number of questions may be asked in order to revisit the objectives of decentralization, e.g. is it true that decentralized resource governance promotes equity and democratic resource management at the local level?; does decentralization genuinely promote resource conservation? In our case study, we found that these stakeholders involved in conflict were unable to resolve their problem in a good way. They were unable to prevent the escalation of the conflict and failed to come up with a win-win solution. They faced stalemate and deadlock. They suffered from conflict both economically and physiologically.

Our study suggests that decentralization does not automatically promote resource conservation. We demonstrated that conflict triggered the logging company to speed up its logging activity. This phenomenon was counter productive for conservation efforts. Given this reality, we tend to agree with Tacconi et al (2006) that decentralization, if not implemented properly, can yield negative consequences. However, we are not advising "recentralization", as we have also learned from the various adverse impacts of Indonesia's previous centralistic system. Rather we are challenging practitioners, researchers and development agencies to continue to look for improvements to the practice of decentralization. The following question needs serious attention: What are the necessary conditions to ensure the achievement of decentralization goals?

Although a full answer to this question will require further research, our study in Sumatra provides several important lessons. First, for decentralization to deliver its optimal goals, issues surrounding property rights need to be addressed seriously. In this study it is very obvious that the main issue in the conflict was differing perceptions of property rights. Therefore, de jure and de facto claims to forests have to be reconciled. The state and the community should engage in negotiation to find solutions to overlapping claims to forest areas. The process of this negotiation can benefit enormously from various research results and can be facilitated by skilled mediators. The District government offices and the DFS must be willing to listen to community aspirations. Ground checks of forest boundaries and 
negotiation on these boundaries are important steps that may be considered to address the conflict. Once the property rights issues have been addressed the implementation of forestry decentralization will have a better grounding and wider acceptance from various stakeholders. Second, decentralization cannot be implemented in "a hurry". It needs preparation. In Indonesia, decentralization was implemented without sufficient care. The legal framework is weak and sometimes also inconsistent (see McCarthy, 2004; Wulan et al. 2004, Tacconi et al. 2006). Clear implementation guidelines and continuous monitoring of the implementation are needed. To ensure this happens, the capacity of governments such as DFS and District government offices need to be improved. They also need to have more specialized knowledge on conflict management. More research on how to optimize decentralization objectives is needed to shed more light and expand our understanding on this matter.

\section{ACKNOWLEDGEMENTS}

We acknowledge the critiques and suggestions from the participants of the $12^{\text {th }}$ biennial conference of the International Association for the Study on Common Property (IASCP) in Cheltenham, U.K in July 2008, where we had the opportunity to present earlier version of this paper. Data collection for this study was done by Y. Yasmi when he was pursuing his $\mathrm{PhD}$ degree under the supervision of Prof. Heiner Schanz of Freiburg University and Prof. Bas Arts of Wageningen University. He is very grateful for their scientific guidance. We would like to thank Marzoni, Hasantoha Adnan, Edy, Linda Yuliani, Yayan Indriatmoko, Rahayu Koesnadi, Iwan Kurniawan and all the ACM team of CIFOR in Sumatra for their assistance in this research. We are very grateful to Yanti Kusumanto who provided constructive and thorough comments on an earlier draft of this paper. We are equally grateful to Doris Capistrano, the former Director of Forests and Governance Program of CIFOR. We are also thankful to two anonymous referee who provided useful comments. Finally, we are indebted to the people of Baru Pelapat, Sumatra who gave us an opportunity to learn about their culture and forest management activities.

\section{REFERENCES}

ADNAN, H., TADJUDIN, D., YULIANI, L., KOMARUDIN, H., LOPULALAN, D., SIAGIAN, Y.L., MUNGGORO, D.W (eds). 2008. Belajar dari Bungo: mengelola sumberdaya alam di era desentralisasi. CIFOR, Bogor. 465pp.

AGRAWAL, A., GUPTA, K. 2005. Decentralization and participation: the governance of common pool resources in Nepal's terai. World Development. 33 (7): 1101-1114.

BARR, C., RESOSUDARMO, I.A., DERMAWAN, A., MCCARTHY, J.F., MOELIONO, M., SETIONO. B. 2006. Decentralization of forest administration in Indonesia: implications for forest sustainability, economic development and community livelihoods. CIFOR, Bogor. 178 pp.

BARTOS, O.J., WEHR, P. 2002. Using conflict theory. Cambridge University Press.232 pp.

BAVINCK, M. 1998. A matter of maintaining peace, state accommodation to subordinate legal systems: the case of fisheries along the Coromandel Coast of Tamil Nadu, India. Journal of Legal Pluralism 40: 151-170.

BAILEY, K.D. 1997. System and conflict: toward a symbolic reconciliation. Quality and Quantity 31: 425-44.

BLENCH, R. 1996. Aspects of resource conflict in semiarid Africa. ODI Natural Resource Perspectives No. 15, November 1996.

BUCKLES, D (ed). 1999. Cultivating peace: conflict and collaboration in natural resource management. IDRC/ World Bank, Ottawa. 300 pp.

CASTRO, A.P., NIELSON, E. 2001. Indigenous people and co-management: implications for conflict management. Environmental Science and Policy 4: 229-239.

CASTRO, A.P., NIELSON. E. 2003. Natural resource conflict management case studies: an analysis of power, participation and protected areas. FAO, Rome. $268 \mathrm{pp}$.

COLFER, C.J.P., RESOSUDARMO, I.A.P (eds) 2002. Which way forward?: people, forests, and policymaking in Indonesia. Resources for the Future and CIFOR. Washington, D.C. 464 pp.

COLFER, C.J.P(ed). 2005. The complex forest: communities, uncertainty, and adaptive collaborative management. Resources for the Future and CIFOR, Washington, DC. 352 pp.

COLFER, J.P.C AND CAPISTRANO, D (eds). 2005. The politics of decentralization: forests, power and people. Earthscan, London. 322 pp.

COLFER, C.J.P., HAKIM, S., ADNAN, H., INDRIATMOKO, Y., IWAN, R., KUSUMANTO, Y., LIMBERG, G., MOELIONO, M., SUDANA, M., WOLLENBERG, E., YULIANI, L. 2005. Case 7: Indonesia. In: COLFER, C.J.P. (ed). The complex forest: communities, uncertainty, and adaptive collaborative management. Resources for the Future and CIFOR, Washington, DC. 352 pp.

COLFER, C.J.P., DAHAL, G.R., CAPISTRANO, D (eds). 2008. Lessons from forest decentralization: money, justice and the quest for good governance in Asia/Pacific. Earthscan and CIFOR, London. 272 pp.

COSER, L.A. 1956. The functions of social conflict. Free Press, New York. 188 pp.

DE JONG, W., RUIZ, S., BECKER, M. 2006. Conflict and communal forest management in Northern Bolivia. Forest Policy and Economics 8 (4): 447-457.

DEUTSCH, M. 1973. The resolution of conflict. Yale University Press, New Haven. 420 pp.

EKADINATA, A., VINCENT, G. 2008. Dinamika tutupan lahan Kabupaten Bungo, Jambi. In: ADNAN, H., TADJUDIN, D., YULIANI, L., KOMARUDIN, H., LOPULALAN, D., SIAGIAN, Y.L., MUNGGORO, D.W (eds). Belajar dari Bungo: mengelola sumberdaya alam di era desentralisasi. CIFOR, Bogor. 465pp.

ENGEL, S AND PALMER, C. 2006. Who owns the right? 
The determinants of community benefits from logging in Indonesia. Forest Policy and Economics 8 (4): 434-446

ENTERS, T., DURST, P. VICTOR, M (eds). 2000. Decentralization and devolution of forest management in Asia and the Pacific. RECOFTC Report N.18 and RAP Publication 2000/1, Bangkok, Thailand. 235 pp.

FAO, 2000. Conflict and natural resource management. FAO, Rome. 21 pp.

GLASL, F. 1999. Confronting conflict: a first-aid kit for handling conflict. Howthorn Press, Gloucestershire. 186 pp.

GUEST, G., BUNCE, A., JOHNSON, L. 2006. How many interviews are enough? an experiment with data saturation and variability. Field Methods 18 (1): 59-82.

HARTANTO, H., LORENZO, M.C., VALMORES, C., ARDA-MINAS, L., BURTON, L., FRIO, A. 2003. Learning together: responding to change and complexity to improve community forests in the Philippines. Bogor, Indonesia: $166 \mathrm{pp}$.

HIRSCHMAN, A.O. 1994. Social conflicts as pillars of democratic market society. Political Theory 22: 203-218.

HO, P. 2006. Credibility of institutions: forestry, social conflict and titling in China. Land Use Policy 23 (4): 588-603.

HOMER-DIXON, T.F. 1999. Environment, scarcity, and violence. Princeton University Press, New Jersey, 272 pp.

HOTTE, L. 2001. Conflict over property rights and natural-resource exploitation at the frontier. Journal of Development Economics 66: 1-21.

INDRIATMOKO, Y. 2002. Hikayat Baru Pelepat. Langkah 1: 3-5.

JENTOFT, S. 2000. Legitimacy and disappointment in fisheries management. Marine Policy 24: 141-148.

KAIMOWITZ, D., VALLEJOS, C., PACHECO, P., LOPEZ, R. 1998. Municipal governments and forest management in lowland Bolivia. Journal of Environmental and Development 7 (1): 45-59.

KAIMOWITZ, D., FLORES, G., JOHNSON, J., PACHECO, P., PAVEZ, I., ROPER, J.M., VALLEJOS, C. AND VELEZ, R. 2000. Local government and biodiversity conservation: a case from the Bolivian lowlands. Biodiversity Support Program, Washington, D.C. 41 pp.

KAPLAN, R.D. 1994. The coming anarchy: how scarcity, crime, overpopulation, and disease are rapidly destroying the social fabric of our planet. Atlantic Monthly: 44-76.

KOMARUDIN, H., SIAGIAN, Y., COLFER, C.J.P.(eds). 2007. Collective action to secure property rights for the poor: a case study in Jambi province, Indonesia. CIFOR for CAPRi (Collective Action and Property Rights). 59 pp.

KRIESBERG, L. 1998. Constructive conflict: from escalation to resolution. Rowman \& Littlefield Publishers Inc, Lanham MD. 448 pp.

KUSUMANTO, T., HAKIM, S., YULIANI, L., INDRIATMOKO, Y., ADNAN, H. 2002. Indonesia country report: planning for sustainability of forests through adaptive co-management. final report to the
Asian Development Bank. Bogor.

KUSUMANTO, T., YULIANI, L., MACOUN, P., INDRAITMOKO, Y., ADNAN, H. 2005. Learning to adapt: managing forest together in Indonesia. CIFOR, Bogor. 193 pp.

LARSON, A.M. 2002. Natural resources and decentralization in Nicaragua: are local governments up to the job? World Development 30 (1): 17-31.

MARDIROS, D. 1997. Fighting for country: aboriginal land associations and common law claims in the Kimberley region of Western Australia. Law and Anthropology 9: 146-157.

MACK, R.W., SNYDER, R. 1957. The analysis of social conflict: toward an overview and synthesis. Conflict Resolution 1 (2): 212-248.

MAYRING P. 2000. Qualitative content analysis. Qualitative social research. FORUM. http://www.qualitativeresearch.net/fqs-texte/2-00/2-00mayring-e.pdf. Cited 12 July 2006.

MCCARTHY, J. F. 2004. Changing to gray: decentralization and the emergence of volatile socio-legal configuration in central Kalimantan, Indonesia. World Development 32 (7): 1199-1223.

MOF (MINISTRY OF FORESTRY OF REPUBLIC OF INDONESIA). 2004. Forest statistics of Indonesia 2003. http://www.dephut.go.id/INFORMASI/STATISTIK/ Stat2003/Stat_03.htm. Cited 28 April 2005.

MULYANA, A., ADNAN, H (eds). 2008. Belajar sambil mengajar: menghadapi perubahan sosial untuk pengelolaan sumberdaya alam. Bogor, CIFOR. 74 pp.

NGAKAN, P.O., ACHMAD, A., WILIAM, D., LAHAE, K., TAKO, A. 2005. The dynamics of decentralization in the forestry sector in South Sulawesi: the history, realities and challenges of decentralized governance. CIFOR, Bogor. 76 pp.

NGUYEN, T.Q. (2008). Decentralization of forest management in Vietnam. In: COLFER, C.J.P., DAHAL, G.R., CAPISTRANO, D (eds). 2008. Lessons from forest decentralization: money, justice and the quest for good governance in Asia/Pacific. Earthscan and CIFOR, London. 272 pp.

NYGREN, A. 2005. Community-based forest management within the context of institutional decentralization in Honduras. World Development 31 (4): 639-5655.

PACHECO, P. 2004. What lies behind decentralization? forest, powers, and actors in lowland Bolivia. European Journal of Development Research 16 (1): 90-109.

PALMER, C. AND ENGEL, S. 2008. For better or for worse? local impacts of the decentralization of Indonesia's forest sector. World Development 35 (12): 2131-2149.

RESOSUDARMO I.A.P. 2004. Closer to people and trees: will decentralization work for the people and the forests of Indonesia? European Journal of Development Research 16(1): 110-132.

RIBOT, J.C AND LARSON, A.M. (eds). 2005. Democratic decentralization through a natural resource lens: cases from Africa, Asia and Latin America. Routledge, London. $244 \mathrm{pp}$ 
RIBOT, J.C., AGRAWAL, A., LARSON, A.M. 2006. Recentralizing while decentralizing: how national governments reappropriate forest resources. World Development 34 (11): 1864-1886.

SARI, E. P. 2007. Kembali ke ladang meggapai asa. In: INDRIATMOKO, Y., YULIANI, L., TARIGA, Y. GABAN, F., MUNGGOR, D., LOPULALAN, D., ADNAN, H (eds). Dari desa ke desa: dinamika gender dan pengelolaan kekayaan alam. CIFOR, Bogor. 131 pp.

SARI, E. P. 2008. Mereka bisa berubah. In: ADNAN, H., TADJUDIN, D., YULIANI, L., KOMARUDIN, H., LOPULALAN, D., SIAGIAN, Y.L., MUNGGORO, D.W (eds). 2008. Belajar dari Bungo: mengelola sumberdaya alam di era desentralisasi. CIFOR, Bogor. 465pp.

SARIN, M., SINGH, N.M., SUNDAR, N., BHOGAL, R.K. 2003. Devolution as a threat to democratic decisionmaking in forestry? findings from three states in India. In: EDMUND, D., WOLLENBERG, E. Local forest management. Earthscan, London. 208 pp.

SCHÄFER, K. 2001. Globalized conflicts of discourse: the type of conflict of proxies. GeoJurnal 52: 45-58.

SCHROEDER-WILDBERG, E., CARIUS, A. 2003. Illegal logging, conflict and the business sector in Indonesia. Adelphi Research, InWEnt - Capacity Building International, Germany. $180 \mathrm{pp}$.

SIKOR, T. 2001. The allocation of forestry land in Vietnam: did it cause the expansion of forests in the Northwest? Forest Policy and Economics 2 (1): 1-11.

SUNDERLIN, W. 2006. Poverty alleviation through community forestry in Cambodia, Laos, and Vietnam: an assessment of the potential. Forest Policy and Economics 8: $386-396$.

TACCONI, L., SIAGIAN, Y., SYAM, R. 2006. On the theory of decentralization, forests and livelihoods. Environmental Management and Development Occasional Paper, ANU, Canberra. 67pp.

VALLADARES-PADUA, C., PADUA, S.M., CULLEN JR, L. 2002. Within and surrounding the Morro do Diabo State park: biological value, conflicts, mitigation and sustainable development alternatives. Environmental Science \& Policy 5: 69-78.

WALKER, G.B AND DANIELS, S.E. 1997. Foundations of natural resource conflict. In SOLBERG, B., MIINA, $\mathrm{S}$ (eds). Conflict management and public participation in land management. EFI Proceedings No. 14. Joensuu. $339 \mathrm{pp}$.

WENBAN-SMITH, J. 2001. Forests of fear: the abuse of human rights in forest conflicts. FERN, Brussels. 48 pp.

WOLLENBERG, E., IWAN, R., LIMBERG, G., MOELIONO, M., RHEE, S., SUDANA, M. 2007. Facilitating cooperation during times of chaos: spontaneous orders and muddling through in Malinau. Ecology and Society 12(1): 3

WORLD BANK. 2007. Decentralization homepage. http:// www1.worldbank.org/wbiep/ decentralization/. Cited 30 March 2007.

WOLLENBERG, E., MOELIONO, M., LIMBERG, G., IWAN, R., RHEE, S., SUDANA, M. 2006. Between state and society: local governance of forests in Malinau, Indonesia. Forest Policy and Economics 8: 421-433.

WULAN, Y.C., YASMI, Y., PURBA, C. WOLLENBERG, E. 2004. Analisa konflik sektor kehutanan di Indonesia 1997 - 2003. CIFOR, Bogor. 79 pp.

YASMI, Y. 2003. Understanding conflict in the comanagement of forests: the case of Bulungan Research Forest. International Forestry Review 5(1): 38-44.

YASMI, Y., ANSHARI, G.Z., ALQADRIE, S., BUDIARTO, T., NGUSMANTO, ABIDIN, E., KOMARUDIN, H., MCGRATH, S., ZULKIFLI, AFIFUDIN. 2005. The complexities of managing forest resources in postdecentralization Indonesia: a case study from Sintang district, West Kalimantan. CIFOR, Bogor. 29 pp.

YASMI, Y., ANSHARI, G.Z., KOMARUDIN, H., ALQADRI, S. 2006. Stakeholder conflicts and forest decentralization policies in West Kalimantan: Their dynamics and implications for future forest management. Forests, Trees and Livelihoods 16 (2): 167-180.

YASMI, Y. 2008. Peningkatan konflik dalam pengelolaan sumberdaya hutan. In: ADNAN, H., TADJUDIN, D., YULIANI, L., KOMARUDIN, H., LOPULALAN, D., SIAGIAN, Y.L., MUNGGORO, D.W (eds). 2008. Belajar dari Bungo: mengelola sumberdaya alam di era desentralisasi. CIFOR, Bogor. 465pp.

YULIANI, L., TADJUDIN, D., INDRIATMOKO, Y., MUNGGORO, D.W., GABAN, F., MAULANA, F., ADNAN, H (eds). 2007. Multistakeholder forestry: steps to change. CIFOR, Bogor. $132 \mathrm{pp}$. 